\title{
IV drug users: changes in risk behaviour according to HIV status in a national survey in Spain
}

Miguel Delgado-Rodríguez, Luis dé lá Fuente, María J Bravo, Pablo Lardelli, Gregorio Barrio

\begin{abstract}
Study objective - To determine whether HIV positive intravenous drug users (IVDUs) who were receiving outpatient treatment for opiate and cocaine abuse or dependence used practices aimed at reducing the spread of HIV.
\end{abstract}

Design - Cross sectional study of behaviour and HIV serostatus in IVDUs.

Setting - A nationwide sample, from 83 health centres for outpatient treatment, stratified by autonomous regions.

Participants - Altogether 1074 IVDUs were recruited. HIV serostatus could be verified in $738(68.7 \%)$ of these.

Measurements and main results - Crude and adjusted odds ratios and their $95 \%$ confidence intervals were estimated to assess the association between HIV serostatus and behavioural changes. In their daily interactions with other members of the same household, seropositive subjects more frequently used preventive methods aimed at avoiding transmission than seronegative patients. Treatment for abuse or dependency before the current regimen had a greater impact in HIV positive than HIV negative subjects in terms of abstaining from risk behaviours. There was a significant trend toward lower drug consumption in HIV positive subjects, and the number of seropositive and seronegative IVDUs who stopped injecting their drugs was significantly higher among the former. Seropositive subjects were also more likely to stop sharing drug injecting equipment and to change their sexual habits; they reported an increased consistent use of condoms.

Conclusions - HIV positive IVDUs were more likely to change their risk behaviours than their HIV negative counterparts.

\section{( $(\mathcal{F}$ Epidemiol Community Health 1994;48:459-463)}

The main strategy in the control of the AIDs epidemic (and of infection with the HIV virus) is health education aimed at motivating people to decrease the frequency of risk behaviours. ${ }^{1}$ Spain, where $66.8 \%$ of all cases of AIDS occur among intravenous drug users (IVDUs), ${ }^{2}$ has the third highest number (after France and Switzerland) of AIDS patients among European countries, according to the WHO European Region Office. ${ }^{3}$ Moreover, problems related to drug abuse in Spain have increased notably in recent years. ${ }^{4}$ Infection with HIV seems to be the factor that has contributed most to the rise in the demand for care as well as in morbidity and mortality among drug users. At the end of 1990, Spain was the European country with the highest cumulative incidence of AIDs related to drug use, and the rate of HIV infection (41-75\%, depending on the group) was among the highest in Europe. ${ }^{5}$ Two factors led to this situation: the early introduction of HIV in the IVDU population and the high incidence of risk behaviours in this population. ${ }^{6}$

Although drug users are often assumed to be unable or unwilling to change their risk behaviours, evidence has been accumulating in recent years that some IVDUs, especially those receiving treatment through programmes aimed at reducing the harmful effects of drug abuse, have adopted safer injecting practices, and, to a lesser extent, safer sexual habits and behaviours in their daily interaction with members of the same household. ${ }^{7-11}$ This study aimed to analyse the changes in behaviour intended to reduce the risk of transmitting HIV in Spanish IVDUs who were receiving outpatient treatment, and the relationship between these changes and HIV serostatus.

\section{Methods}

The reference population for this study comprised IVDUs in Spain who were receiving outpatient treatment for opiate or cocaine abuse or dependency between 1 April 1989 and 30 September 1989. The methodology has been described elsewhere. ${ }^{12}$ Briefly, by 1988 an extensive, nationwide network of health centres for outpatient treatment (Centros de Tratamiento Ambulatorio, CTA) provided care and treatment for opiate or cocaine dependency. These centres, most of which are administered by the Spanish national health system, are usually the first place to which a drug user who is seeking treatment goes. Since 1987, most CTAs regularly notify the State Information System on Toxic Substance Abuse (Sistema Estatal de Información sobre Toxicomanias, SEIT) of each new patient seen (Delegación del Gobierno, 1991b $\left.{ }^{13}\right)$. When necessary, the CTA refers the patient to other treatment centres (for example, a hospital or residential therapy community). These centres do not notify the SEIT of new admissions, as they usually receive patients referred from the CTA, although a few patients are referred from other centres. ${ }^{14}$ The treatments reported to the SEIT therefore constitute an accurate record of outpatient treatment of opiate and cocaine abuse or dependency in Spain, given the widespread 
availability of treatment through the CTAs, and the high compliance in reporting. ${ }^{15}$

In 1988, the SEIT received notifications from 251 centres. ${ }^{16}$ Ninety centres were randomly selected in such a way as to obtain a proportional representation of each of the 17 autonomous regions in Spain. After inviting these centres to participate in the study, nine declined (similar to participating centres in size and type of ownership), of which suitable substitutes were found for two. Therefore, altogether 83 CTA, located throughout the country, participated. At each centre, patients who received treatment for opiate and/or cocaine abuse or dependency between 1 April 1989 (not necessarily starting on this date) and 30 September 1989 were randomly selected. The number of patients studied from each centre was determined by a proportional sample, based on the entire population of the autonomous region in which the CTA was located. In all, 1233 patients were recruited, of whom 1074 (the final sample) were IVDUs. IVDUs were defned as subjects who had injected substances intravenously at least once during the six months preceding the start of treatment. Altogether $738(68.7 \%)$ IVDUs reported that they knew their HIV serostatus (and this was verified by the CTA) when they were recruited for the study. In the remaining $31.3 \%$ of IVDUs the HIV serostatus was unknown: $104(9.7 \%)$ did not consent to the test, $109(10.1 \%)$ were unaware of their HIV serostatus because they had not been tested before the study, the result was not verified by the centre in $115(10.7 \%)$, and data were missing for seven. Each collaborating centre was in charge of providing HIV testing for their patients; an ELISA was used and the result was confirmed by western blot analysis. CTAs sent a copy of the results to the coordinating centre. No central laboratory analyses were performed.

Table 1 General characteristics of the study population

\begin{tabular}{|c|c|c|c|c|c|}
\hline & \multicolumn{3}{|l|}{ HIV status } & & \\
\hline & \multirow{2}{*}{$\begin{array}{l}\text { Positive } \\
(n=306) \\
\text { No }(\%)\end{array}$} & \multirow{2}{*}{$\begin{array}{l}\text { Negative } \\
\left(\begin{array}{l}n=432) \\
\text { No }(\%)\end{array}\right.\end{array}$} & \multirow{2}{*}{$\begin{array}{l}\text { Unknown } \\
(n=336) \\
\text { No }(\%)\end{array}$} & \multicolumn{2}{|l|}{ p value } \\
\hline & & & & * & $* *$ \\
\hline $\begin{array}{l}\text { Sex: } \\
\text { Male } \\
\text { Female } \\
\text { Not available }\end{array}$ & $\begin{array}{r}248(81 \cdot 0) \\
57(18 \cdot 6) \\
1(0 \cdot 3)\end{array}$ & $\begin{array}{r}353(81.7) \\
77(17.8) \\
2(0.5)\end{array}$ & $\begin{array}{r}285(84 \cdot 8) \\
51(15 \cdot 2)\end{array}$ & $\begin{array}{l}0.862 \\
\text { (Fisher's }\end{array}$ & $\begin{array}{l}0 \cdot 250 \\
\text { s test) }\end{array}$ \\
\hline $\begin{array}{l}\text { Age (y): } \\
<20 \\
20-24 \\
25-29 \\
30-34 \\
>34 \\
\text { Not available }\end{array}$ & $\begin{array}{r}13(4 \cdot 2) \\
92(30 \cdot 1) \\
131(42 \cdot 8) \\
53(17 \cdot 3) \\
17(5 \cdot 6)\end{array}$ & $\begin{array}{r}44(10 \cdot 2) \\
183(42 \cdot 4) \\
150(34 \cdot 7) \\
45(10 \cdot 4) \\
8(1.9) \\
2(0.5)\end{array}$ & $\begin{array}{r}24(7 \cdot 1) \\
138(41.1) \\
122(36 \cdot 3) \\
42(12 \cdot 5) \\
10(3.0)\end{array}$ & $\begin{array}{l}0.00 \\
3 \mathrm{df}\end{array}$ & 0.846 \\
\hline $\begin{array}{l}\text { Education: } \\
\text { Less than primary } \\
\text { Primary school } \\
\text { Secondary school } \\
\text { University }\end{array}$ & $\begin{array}{r}27(8 \cdot 8) \\
186(60 \cdot 8) \\
81(26 \cdot 5) \\
12(3 \cdot 9)\end{array}$ & $\begin{array}{r}30(6 \cdot 9) \\
243(56 \cdot 3) \\
135(31 \cdot 3) \\
24(5 \cdot 6)\end{array}$ & $\begin{array}{r}32(9.5) \\
198(58 \cdot 9) \\
88(26 \cdot 2) \\
18(5 \cdot 4)\end{array}$ & $\begin{array}{l}0 \cdot 280 \\
3 \mathrm{df}\end{array}$ & 0.314 \\
\hline $\begin{array}{l}\text { No of treatments: } \\
1 \\
2 \\
3 \\
4 \\
5+\end{array}$ & $\begin{aligned} 105(34 \cdot 3) \\
88(28 \cdot 8) \\
58(19 \cdot 0) \\
25(8 \cdot 2) \\
20(6 \cdot 5) \\
10(3 \cdot 3)\end{aligned}$ & $\begin{array}{r}206(47 \cdot 7) \\
117(27 \cdot 1) \\
69(16 \cdot 0) \\
25(5 \cdot 8) \\
13(3 \cdot 0) \\
2(0 \cdot 5)\end{array}$ & $\begin{array}{r}175(52 \cdot 1) \\
79(23 \cdot 5) \\
46(13 \cdot 7) \\
16(4 \cdot 8) \\
14(4 \cdot 2) \\
6(1 \cdot 8)\end{array}$ & $\begin{array}{l}0.000 \\
5 \mathrm{df}\end{array}$ & 0.000 \\
\hline
\end{tabular}

* Comparison HIV + $v$ HIV -

** Comparison known HIV $v$ unknown HIV serostatus. $\mathrm{df}=$ degrees of freedom.
All participants were interviewed by one of the field workers, who were trained to fill in a two part questionnaire based on that used by the US National Institute on Drug Abuse $^{17}$ to assess people belonging to groups at risk for HIV infection. The first part contained 145 questions to be answered by the patients, and collected basic demographic information and data on their frequency and habits of drug consumption, sexual habits, and daily interaction with other members of the household; knowledge of HIV and its modes of transmission; desired treatment and changes in risk behaviours after treatment for drug dependency (in ambulatory centres, hospitals or in therapeutic communities) or after learning of their HIV positive serostatus. Previous treatments indicate more contact with the health system, one of the most important sources of knowledge about HIV transmission in the study population (data not shown). The second group of questions, to be answered by the coordinators of each centre, was used to verify the information provided by patients on their HIV serostatus.

All patients were interviewed between 1 April 1989 and 30 September 1989, and coordinators' responses were obtained between 1 April and 30 November 1989.

The data were analysed with the BMDP statistical package (1988 version). The $\chi^{2}$ statistic, and Fisher's exact test for small sample sizes, were used for comparison of proportions among HIV positive and HIV negative patients. The strength of the association between two variables (HIV serostatus and behavioural change after notification) was estimated as the odds ratio (OR) and its 95\% confidence interval. Because of the presence of confounding factors, adjusted odds ratios were calculated by logistic regression. A preliminary analysis pointed to age, educational level, and number of treatments received previous to the one in course when the study was performed as the possible confounding factors. Adjustment for other variables did not change substantially the estimates obtained by adjusting on the basis of the above variables.

\section{Results}

Several general characteristics of the study population are displayed in table 1 . HIV positive subjects, did not show a significantly different distribution from HIV negative subjects in relation to sex and education level but HIV positive subjects showed a statistically significant trend to be older and have initiated fewer courses of treatment for drug use than HIV negative subjects. IVDUs with unknown HIV serostatus showed a trend to have initiated fewer treatments; the remaining variables did not show significant differences.

Table 2 shows the relation between HIV serostatus and the adoption by Spanish IVDUs of measures to avoid transmitting HIV. Only $9.1 \%$ reported taking no precautions in their daily interactions with other members of the household, and $9 \cdot 1 \%$ took precautions with regard to cooking and eating utensils (this last figure reflecting the misunderstanding of the 
Table 2 Adoption by intravenous drug users of measures to prevent HIV transmission to other members of the household after notification of HIV serostatus

\begin{tabular}{|c|c|c|c|c|c|}
\hline & $\begin{array}{l}H I V+v e \\
(n=306)\end{array}$ & $\begin{array}{l}H I V-v e \\
(n=432)\end{array}$ & $\begin{array}{l}\text { Total } \\
(n=738)(\%)^{*}\end{array}$ & OR $(95 \% C I) \dagger$ & OR $(95 \% C I)_{\ddagger}^{\ddagger}$ \\
\hline $\begin{array}{l}\text { Not sharing shaving equipment } \\
\text { Not sharing toothbrush } \\
\text { Not sharing cooking and } \\
\text { eating utensils }\end{array}$ & $\begin{array}{r}198 \\
238 \\
29\end{array}$ & $\begin{array}{r}261 \\
317 \\
38\end{array}$ & $\begin{array}{r}459(62 \cdot 2) \\
555(75 \cdot 2) \\
67(9 \cdot 1)\end{array}$ & $\begin{array}{l}1 \cdot 84(1 \cdot 04,3 \cdot 23) \\
1.82(1 \cdot 04,3 \cdot 18) \\
1.85(0.90,3 \cdot 80)\end{array}$ & $\begin{array}{l}1 \cdot 85(1 \cdot 00,3 \cdot 44) \\
1 \cdot 70(0 \cdot 92,3 \cdot 12) \\
1 \cdot 76(0 \cdot 75,4 \cdot 15)\end{array}$ \\
\hline $\begin{array}{l}\text { All the above } \\
\text { None of the above }\end{array}$ & $\begin{array}{l}30 \\
19\end{array}$ & $\begin{array}{l}37 \\
46\end{array}$ & $\begin{array}{ll}67 & (9 \cdot 1) \\
65 & (8 \cdot 8)\end{array}$ & $\begin{array}{l}1.96(0.96,4.03) \\
1 \text { (Reference) }\end{array}$ & $\begin{array}{l}2 \cdot 01(0 \cdot 89,4 \cdot 54) \\
1 \text { (Reference) }\end{array}$ \\
\hline
\end{tabular}

* Numbers do not add totals because participants could choose several options.

+ Crude estimates.

†stimates adjusted for age, education level, and number of treatments received.

mode of HIV transmission). When these findings were examined in the light of HIV serostatus, HIV positive subjects more frequently took precautions than those who were HIV negative (crude and adjusted results).

Part of the survey investigated the possible influence of previous treatments for drug abuse or dependence on the adoption of healthier habits aimed at impeding the transmission of HIV (table 3 ). Only $21.4 \%$ of the IVDUs questioned said that previous treatment had had no effect on their behaviour. More than one third of the sample $(36 \%)$ said they used sterile injecting equipment more frequently after treatment, whereas only $14.8 \%$ reported increased condom use. These changes were more noticeable among HIV positive subjects, as shown by the significant OR values greater than unity (lower confidence limit greater than 1).

The changes in the intensity of parenteral drug consumption after subjects had been notified of their HIV serostatus are summarised in table 4 . This question was left blank by $30 \cdot 1 \%$ (24.5\% of HIV positive and $34.0 \%$ of HIV negative) subjects $\left(\chi^{2}=7 \cdot 27, p<0 \cdot 01\right)$. A small number of subjects $(5 \cdot 1 \%)$ reported increasing drug use after learning their serostatus. Although the increase was greater among HIV positive than HIV negative subjects, the OR failed to reach statistical significance in the multivariate analysis. In contrast, $29.5 \%$ of the IVDUs reduced drug consumption after notification of their serostatus. The decrease was greater among HIV positive subjects, with the OR showing a significant difference between the seropositive and seronegative groups.

Knowledge of HIV serostatus also affected the form and intensity of drug consumption (table 5). Favourable changes were reported by $51.2 \%$, and no change by $23.7 \%$, while $25.2 \%$ $(22.5 \%$ of HIV positive and $27 \cdot 1 \%$ of HIV negative) subjects left this item blank $\left(\chi^{2}=1 \cdot 72\right.$. $\mathrm{p}=0 \cdot 19$ ). In general, HIV positive subjects more frequently reported positive changes, except with regard to the use of sterile injecting equipment (obtained in pharmacies), and in the category termed "other".

Changes in sexual behaviour as a result of HIV serostatus are shown in table 6 . This item was left unanswered by $25.3 \%$ of the subjects $(21.9 \%$ HIV positive $v 27.8 \%$ HIV negative, $\mathrm{p}=0 \cdot 14$ ). Only $37 \cdot 7 \%$ reported changing their behaviour after learning of their serostatus, a figure much lower than those for other behavioural changes described above. As in other aspects of behaviour, favourable changes were significantly more frequent among HIV positive than HIV negative IVDUs.

Table 3 Influence of previous treatment on changes in risk behaviour to prevent the transmission of HIV after notification of HIV serostatus

\begin{tabular}{|c|c|c|c|c|c|}
\hline Behaviour & $\begin{array}{l}H I V+v e \\
(n=306)\end{array}$ & $\begin{array}{l}H I V-v e \\
(n=432)\end{array}$ & $\begin{array}{l}\text { Total } \\
(n=738)(\%)^{*}\end{array}$ & $O R(95 \% C I) \dagger$ & OR $(95 \% C I)_{+}^{+}$ \\
\hline $\begin{array}{l}\text { Increased use of sterile syringes } \\
\text { Increased condom use } \\
\text { Increased precautions with } \\
\text { other household members }\end{array}$ & $\begin{array}{r}120 \\
67 \\
161\end{array}$ & $\begin{array}{r}146 \\
42 \\
154\end{array}$ & $\begin{array}{l}266(36 \cdot 0) \\
109(14 \cdot 8) \\
315(42 \cdot 7)\end{array}$ & $\begin{array}{l}1 \cdot 78(1 \cdot 17,2 \cdot 68) \\
3 \cdot 44(2 \cdot 07,5 \cdot 74) \\
2 \cdot 26(1 \cdot 51,3 \cdot 37)\end{array}$ & $\begin{array}{l}1 \cdot 71(1 \cdot 09,2 \cdot 66) \\
3 \cdot 75(2 \cdot 16,6 \cdot 49) \\
2 \cdot 27(1 \cdot 47,3 \cdot 49)\end{array}$ \\
\hline No influence & 50 & 108 & $158(21 \cdot 4)$ & 1 (Reference) & 1 (Reference) \\
\hline
\end{tabular}

* Numbers do not add totals because participants could choose several options.

+ Crude estimates.

$\ddagger$ Estimates adjusted for age, education level, and number of treatments received.

Table 4 Changes in consumption of intravenous drugs after notification of HIV serostatus

\begin{tabular}{lccccc}
\hline Behaviour & $\begin{array}{c}H I V+v e \\
(n=306)\end{array}$ & $\begin{array}{l}\text { HIV }(n=432) \\
(n=432\end{array}$ & $\begin{array}{l}\text { Total } \\
(n=738)(\%)\end{array}$ & $O R(95 \% C I)^{*}$ & $O R(95 \% C I) \dagger$ \\
\hline Increased consumption & 23 & 15 & $38(5 \cdot 1)$ & $2 \cdot 45(1 \cdot 22,4 \cdot 92)$ & $2 \cdot 11(0 \cdot 99,4 \cdot 51)$ \\
Decreased consumption & 108 & 110 & $218(29 \cdot 5)$ & $1 \cdot 57(1 \cdot 09,2 \cdot 26)$ & $1 \cdot 71(1 \cdot 15,2 \cdot 54)$ \\
No change & 100 & 160 & $260(35 \cdot 2)$ & 1 (Reference) & $1($ Reference) \\
No answer & 75 & 147 & $222(30 \cdot 1)$ & & \\
\hline
\end{tabular}

* Crude estimates.

+ Estimates adjusted for age, education level, and number of treatments received. 
Table 5 Changes in the type and route of administration of intravenuous drugs after notification of HIV serostatus

\begin{tabular}{|c|c|c|c|c|c|}
\hline Behaviour & $\begin{array}{l}H I V+v e \\
(n=306)\end{array}$ & $\begin{array}{l}H I V-v e \\
(n=432)\end{array}$ & $\begin{array}{l}\text { Total } \\
(n=738)(\%)^{*}\end{array}$ & OR $(95 \% C I) \dagger$ & OR $(95 \% C I) \ddagger$ \\
\hline $\begin{array}{l}\text { Stopped intravenous injection } \\
\text { Decreased intravenous injection } \\
\text { Stopped sharing } \\
\text { injection equipment }\end{array}$ & $\begin{array}{l}25 \\
43 \\
58\end{array}$ & $\begin{array}{l}29 \\
41 \\
40\end{array}$ & $\begin{array}{l}54(7 \cdot 3) \\
84(11 \cdot 4) \\
98(13 \cdot 3)\end{array}$ & $\begin{array}{l}1.46(0.79,2 \cdot 70) \\
1.77(1.05,3 \cdot 00) \\
2.45(1.48,4 \cdot 07)\end{array}$ & $\begin{array}{l}1 \cdot 76(0 \cdot 88,3 \cdot 51) \\
2 \cdot 01(1 \cdot 15,3 \cdot 50) \\
2 \cdot 01(1 \cdot 16,3 \cdot 49)\end{array}$ \\
\hline Decreased sharing & 38 & 25 & $63 \quad(8.5)$ & $2 \cdot 57(1 \cdot 43,4 \cdot 64)$ & $2 \cdot 70(1 \cdot 40,5 \cdot 21)$ \\
\hline $\begin{array}{l}\text { Used only sterile equipment } \\
\text { (from pharmacies) }\end{array}$ & 36 & 49 & $85(11 \cdot 5)$ & $1 \cdot 24(0 \cdot 73,2 \cdot 11)$ & $1 \cdot 20(0 \cdot 66,2 \cdot 17)$ \\
\hline $\begin{array}{l}\text { Increased disinfection } \\
\text { of equipment }\end{array}$ & 41 & 33 & $74(10 \cdot 0)$ & $2 \cdot 10(1 \cdot 21,3 \cdot 65)$ & $2 \cdot 33(1 \cdot 27,4 \cdot 30)$ \\
\hline $\begin{array}{l}\text { Other } \\
\text { No change } \\
\text { No answer }\end{array}$ & $\begin{array}{l}30 \\
65 \\
69\end{array}$ & $\begin{array}{r}59 \\
110 \\
117\end{array}$ & $\begin{array}{r}89(12 \cdot 1) \\
175(23 \cdot 7) \\
186(25 \cdot 2)\end{array}$ & $\begin{array}{l}0.86(0.50,1 \cdot 47) \\
1 \text { (Reference) }\end{array}$ & $\begin{array}{l}0.95(0.52,1.76) \\
1 \text { (Reference) }\end{array}$ \\
\hline
\end{tabular}

* Numbers do not add totals because participants could choose several options.

+ Crude estimates.

$\$$ Estimates adjusted for age, education level, and number of treatments received.

Table 6 Changes in sexual habits by intravenous drug users after notification of their HIV serostatus

\begin{tabular}{llllll}
\hline Behaviour & $\begin{array}{c}\text { HIV+ve } \\
(n=306)\end{array}$ & $\begin{array}{l}\text { HIV }(n=432) \\
(n=43)\end{array}$ & $\begin{array}{l}\text { Total } \\
(n=738)(\%)^{*}\end{array}$ & OR $(95 \% C I) \dagger$ & OR $(95 \% C I)^{\ddagger}$ \\
\hline Less frequent sexual relations & 74 & 41 & $115(15 \cdot 6)$ & $4 \cdot 13(2 \cdot 61,6 \cdot 55)$ & $3 \cdot 95(2 \cdot 37,6 \cdot 58)$ \\
Fewer sexual partners & 33 & 25 & $58(7 \cdot 9)$ & $3 \cdot 02(1 \cdot 69,5 \cdot 40)$ & $2 \cdot 74(1 \cdot 45,5 \cdot 19)$ \\
Increased condom use & 42 & 41 & $83(11 \cdot 2)$ & $2 \cdot 34(1 \cdot 42,3 \cdot 87)$ & $2 \cdot 72(1 \cdot 56,4 \cdot 72)$ \\
Consistent condom use & 55 & 13 & $68(9 \cdot 2)$ & $9 \cdot 68(5 \cdot 02,18 \cdot 7)$ & $9 \cdot 17(4 \cdot 56,18 \cdot 5)$ \\
Other & 23 & 26 & $49(6 \cdot 6)$ & $2 \cdot 03(1 \cdot 09,3 \cdot 74)$ & $2 \cdot 01(1 \cdot 01,4 \cdot 01)$ \\
No change & 83 & 190 & $273(37 \cdot 0)$ & 1 (Reference) & 1 (Reference) \\
No answer & 67 & 120 & $187(25 \cdot 3)$ & & \\
\hline
\end{tabular}

* Numbers do not add totals because participants could choose several options.

+ Crude estimates.

† Estimates adjusted for age, education level, and number of treatments received.

\section{Discussion}

Our findings show that Spanish IVDUs who receive outpatient treatment reduce the frequency of high risk behaviours after they have been told their HIV serostatus. This type of change has also been documented in other prevalence studies. ${ }^{18}$ Although the cross sectional rather than longitudinal study design limits the inferential power of our data with regard to long term behavioural change, the modifications reported by our sample of IVDUs in Spain are supported by observations in other countries. For example, a cohort analysis of drug users in San Francisco (USA) receiving outpatient treatment showed that fewer IVDUs shared injecting equipment after learning of their HIV serostatus. ${ }^{1}$ Other cohort studies have reported similar findings, ${ }^{1920}$ as well as a decrease in intravenous drug use. ${ }^{20}$

Changes in sexual behaviour have also been found. Our figure $(37 \cdot 7 \%)$ was lower than the $61 \%$ who reported having changed behaviours to prevent HIV transmission in a study by Abdul-Quader. ${ }^{21}$ The frequency of consistent condom use among our subjects $(9 \cdot 2 \%)$ was similar to the $12 \%$ reported by Magura et al, ${ }^{22}$ and below the $21 \%$ figure given by Donoghoe $e t$ $a l^{23}$ for a sample of 142 IVDUs who participated in a needle exchange programme. The proportion of subjects who reduced the number of sexual partners, however, was notably greater in our study than in that of Donoghoe $e t$ $a .^{23}$

In general, our findings suggest that HIV positive subjects make more behavioural changes than HIV negative subjects, although a considerable number of the former report no change in the frequency or types of risk behaviours. An Italian study yielded similar findings: changes in sexual behaviour and drug consumption were more frequent among HIV positive patients. Other studies have also documented the more frequent adoption of practices with a lower risk of transmitting the virus among HIV positive subjects. ${ }^{2425} \mathrm{~A}$ study of a smaller population (69 opiate addicts participating in a methadone treatment programme) ${ }^{26}$ also reported that HIV positive subjects were more likely to take steps to reduce the possibility of HIV transmission.

Some of our results, however, differed from those in other studies of more circumscribed populations. Nemoto et $a l^{7}$ reported that none of their HIV positive subjects used condoms, compared with $18 \%$ of our subjects who always used condoms, and $13.7 \%$ who used them more frequently, after learning of their serostatus. Martin et $a l^{28}$ found no relation between seropositive status and a reduction in the number of sexual partners, in contrast to our data $(\mathrm{OR}=2 \cdot 74,95 \%$ CI $1.45,5 \cdot 19)$. In general, sexual behaviour in our subjects changed less frequently than drug use behaviour $(37.7 \% v$ $51.2 \%$ ), as was also found in a nationwide Italian study. ${ }^{24}$ These findings support the conclusion of Conviser and Rutledge ${ }^{29}$ that it is more difficult to change sexual behaviour than drug injecting behaviour.

The implications and applicability of our findings are limited by a number of considerations, foremost of which is the cross sectional study design used. Firstly, this type of study may be affected by selections bias: the HIV positive subjects we surveyed may have been 
those who most frequently took measures to reduce the risk of HIV transmission. The findings of other cross sectional studies seem to rule out this source of bias, however, as the frequency of risky behaviours decreases with time. ${ }^{1920}$ On the basis of personal risk criteria, there is no reason to believe a priori that HIV positive subjects are more highly motivated to change their behaviour. Unfortunately, they are only too aware that nothing they can do can change their serostatus.

A second limitation of the present cross sectional study in comparison with the longitudinal design is that the former provides no information on the persistence of the behaviours adopted in response to serostatus.

A third consideration is the fact that the serological analyses were performed by many different laboratories rather than a single, centralised institution, and lack of standardisation may have lead to misclassification of some patients. Because all laboratories used a similar analytical technique, however, we have no reason to suspect that the bias was differential: if the error were in fact non-differential, this would skew the values of the OR toward zero, ${ }^{31}$ which would favour our conclusion that the actual value of association is at least as high as the observed value.

Finally, many subjects (about 30\%) left some of the questions in the questionnaire unanswered. The trend was for more HIV negative than HIV positive subjects to leave certain items blank. If we assume that the behaviour of those who left blanks was more rather than less likely to transmit HIV, then the greater number of "not available" answers among HIV negative subjects would skew the data toward a null result. On the contrary, this may be also due to a misunderstanding of the questions (problems with the wording or terminology) or to less knowledge among HIV negative patients producing the opposite effect. Because we do not actually know whether the behaviour of those who failed to answer all the questions favoured or prevented HIV transmission, we cannot draw any conclusions on this point. A comparison of answerers and non-answerers on the basis of demographic variables did not show significant differences in background between these two groups.

Our findings show that changes in risk behaviour were more frequent among seropositive than seronegative IVDUs. This suggests that the former group decrease the likelihood of transmitting HIV to seronegative IVDUs and the general population. The considerable number of HIV positive subjects who reported no change in risk behaviours however constitutes a source of high risk of infection; this group requires concerted educational efforts and public health measures.

This study was supported by funds provided by the Government Office of the National Plan on Drugs (Ministry of Health), Spain.

We thank Ms Karen Shashok for help with translating the original manuscript into English.

1 Guydish JR, Abramowitz A, Woods W, Black DM, Sorensen JL. Changes in needle sharing behaviour among intravenous drug users: San Francisco, 1986-88. Am $\mathcal{f}$ Public vealth 1990;80:995-7.
2 Anonymous. Sindrome de inmunodificiencia adquirida. situación en España 2 de abril de 1991. Boletín Epidemiológico Semanal 1991;1885:65-67.

3 world Health Organization. Acquired immunodeficiency syndrome (AIDS). WHO European region update to 30 September 1990. Wkly Epidemiol Rec 1991;66:33-38.

4 Cami J, Barrio G. Drug consumption in Spain: trends, implications and policies. In: Conference on American and European drug policies: comparative perspectives. WashEuropean drug policies: comparative perspectives.

5 Fernández-Sierra MA, Gómez-Olmedo MR, Delgado-Rodríguez $M$, Gálvez-Vargas $R$. Infección por VIH en la población española. Ii. Metaanálisis de las tendencias temporales y geográficas. Med Clin (Barc) 1990;95:366-71.

6 Bravo MJ, de la Fuenta L. Epidemiologia de la infección por VIH en los usuarios de drogas por via parenteral. Pub of Soc Esp Interdisc Sida 1991;2:335-41.

7 Hartgers C, Bunning EC, van Santen GW, Versters A, Coutinho RA. The impact of the needle and syringeexchange program in Amsterdam on injecting risk behaviour. AIDS 1989;3:571-6.

8 Stimson GV, Syringe exchange programs for injecting drug users. AIDS 1989;3:253-60.

9 Power R, Stimson GV, Strang J. Drug prevention and HIV policy. AIDS 1990;4(suppl 1):s263-7.

10 Strang J, Andrew J, Gossop M. Social and drug-taking behaviour of 'maintained' opiate addicts. Br $\mathcal{J}$ Addict 1990;85:771-4.

11 Kleiber D. Behavioural changes in the German intravenous drug use subculture. In: Community Epidemiology Work Group (CEWG). Epidemiology Trends in Drug Abuse. Proceedings, December 1990. DHHS publication no (Adm) 91-1773. Rockville: National Institute on Drug Abuse, 1991.

12 Delegación del Gobierno para el Plan Nacional sobre Drogas. Infeccion por VIH en usuarios de drogas. Madrid: Ministerio de Salud y Consumo, 1991.

13 Delegación del Gobierno para el Plan Nacional sobre Drogas. Sistema Estatal de Información sobre Toxicomanias (SEIT). Protocolo. Madrid: Delegación del Gobierno para el Plan Nacional sobre Drogas, 1991.

14 Grupo de Trabajo del SEIT. Admisiones a tratamiento por opiáceos o cocaina. Gac Sanit. 1990;4:4-11.

15 Sánchez J, Romo T, Rodriguez B, Barrio G. Consumo de drogas en España: Fuentes de información y evolución durante el periodo 1984-1990. Rev Sanid Hig Publica 1991;65:395-412.

16 Delegación del Gobierno para el Plan Nacional sobre Drogas. Sistema estatal de información sobre toxicomanias (SEIT). Informe año 1988. 2nd ed. Madrid: Ministerio de Sanidad y Consumo, 1990.

17 NIDA. AIDS initial assessment questionnaire. AIA-8.0. National AIDS demonstration research projects. National Institute on Drug Abuse. Community Research Brand, Institute on 1,1988 .

18 Vlahov D, Anthony JC, Celentano D, Solomon L, Chowdhury N. Trends of HIV-1 risk reduction among initiates into intravenous drug use 1982-1987. Am $\mathcal{F}$ Drug Alcohol Abuse 1991;17:39-48.

19 Robert CF, Deglon JJ, Wintsch J, et al. Behavioural changes in intravenous drug users in Geneva: rise and fall of HIV infection, 1980-1989. AIDS 1990;4:657-60.

20 Stephens RC, Feucht TE, Roman SW. Effects of an intervention program on AIDS-related drug and needle behaviour among intravenous drug users. $A M f$ Public Health 1991;81:568-71.

21 Abdul-Quader AS, Tross S, Friedman SR, Kouzi AC, des Jarlais DC. Street- recruited intravenous drug users and Jexual risk reduction in New York City. AIDS sexual risk redu

22 Magura S, Shapiro JL, Siddiqi Q, Lipton DS. Variables influencing condom use among intravenous drug users. Am f Public Health 1990;80:82-4.

23 Donoghoe MC, Stimson GV, Dolan KA. Sexual behaviour of injecting drug users and associated risks of HIV infection for non-injecting sexual partners. AIDS Care 1989;1:51-8.

24 Sasse H, Salmaso S, Conti S. Risk behaviors for HIV-1 infection in Italian drug users: report from a multicenter study. First drug user multicenter study group. Fournal of Acquired Immune Deficiency Syndrome 1989;2:486-96.

25 Salmaso S, Conti S, Sasse H. Drug use and HIV-1 infection: report from the second Italian multicenter study. Fournal report from the second Italian multicenter study. Fournal
of Acquired Immune Definiency Syndrome 1991;4:607-13.

of Acquired Immune Definiency Syndrome 1991;4:607-13.
26 Williams H, Mullan E, O'Connor JJ, Kinsella A. Risk behaviour for HIV transmission in attenders on methadone behaviour for HIV transmission in attenders
maintenance. Ir f Med Sci 1990;159:141-4.

27 Nemoto T, Brown LS, Foster K, Chu A. Behavioral risk factors of human immunodeficiency virus infection among intravenous drug users and implications for preventive interventions. AIDS Educ Prev 1990;2:116-126.

28 Martin JL, Garcia MA, Beatrice ST. Sexual behavior changes and HIV antibody in a cohort of New York City gay men. Am $千$ Public Health 1989;79:501-3.

29 Conviser R, Rutledge JH. The need for innovation to halt AIDS among intravenous drug users and their sexua partners. AIDS Public Policy fournal 1988;3:43-50.

30 Joseph JG, Adib M, Koopman JS, Ostrow DG. Behavioral change in longitudinal studies: adoption of condom use by 1990;80:1513-14.

31 Kleinbaum DG, Kupper LL, Morgenstern H. Epidemiologic research. Principles and quantitative methods. Belmont (CA): Lifetime Learning Publications, 1982 